\title{
ANALISIS KANDUNGAN FORMALIN PADA IKAN ASIN DI PASAR TRADISIONAL SUKABUMI SERTA HUBUNGANNYA DENGAN PENGETAHUAN PENJUAL TENTANG FORMALIN
}

\author{
Analysis of Formalin Content in Salted Fish in Traditional Sukabumi Markets and \\ Its Relationship with Seller's Knowledge of Formalin
}

\author{
Siti Ulfah Fauzia Hasanah ${ }^{1}$, M. Fakih Kurniawan ${ }^{1}$, Siti Aminah $^{1}$ \\ ${ }^{1}$ 1Jurusan Teknologi Pangan dan Gizi, Fakultas Ilmu Pangan Halal Universitas \\ Djuanda Bogor Jl. Tol Ciawi No.1, Kotak Pos 35 Ciawi, Bogor 16720 \\ siti.ulfah@unida.ac.id
}

\begin{abstract}
Fish is a food ingredient that is often used as a source of animal protein by humans, fish is very easy to decompose, quickly rotting makes fishermen preserve fish by salting and drying, but many producers and even sellers add formalin to salted fish to make it more durable. The purpose of this study was to analyze the formalin content in salted fish and the knowledge of traders in the $X$ and $Y$ Sukabumi markets and the correlation between the two. Analysis of formaldehyde content used a test kit, while the analysis of traders' knowledge of formalin used questionnaire data. Furthermore, the chi square test and fisher test were carried out to determine the relationship between the knowledge of traders about formalin and the use of formalin. The result was that 4 out of 30 samples of salted fish were positive for formalin. Analysis of knowledge about formaldehyde showed that 9 sellers had high knowledge and 6 people had low knowledge about formalin. The results of the chi square analysis showed that there was no relationship between the use of formalin in salted fish and the seller's knowledge of formalin with a significance value of $0.634(P>0.05)$ and a fisher exact test value of $1(>0.05)$ and the results of the Pearson correlation test show a significance value of $0.662(p>0.05)$
\end{abstract}

Keyword: formalin, formalin knowledge, salted fish.

\begin{abstract}
ABSTRAK
Ikan merupakan bahan pangan yang sering dijadikan sumber protein hewani oleh manusia, ikan merupakan bahan pangan yang sangat mudah membusuk, agar tidak cepat busuk maka ikan dapat diawetkan dengan penggaraman dan penjemuran, tetapi banyak produsen bahkan penjual yang menambahkan formalin kedalam ikan asin agar lebih awet. Tujuan penelitian ini adalah menganalisis kandungan formalin pada ikan asin dan pegetahuan pedagangnya di pasar X dan Y Sukabumi serta korelasi keduanya. Analisis kandungan formalin menggunakan test kit, sedangkan analisis pengetahuan pedagang tentang formalin menggunakan data kuesioner. Selanjutnya dilakukan uji chi square dan fisher exact test untuk mengetahui hubungan antara pengetahuan pedagang tentang formalin dengan penggunaan formalin. Hasilnya didapatkan bahwa 4 dari 30 sampel ikan asin mengandung formalin. Analisis pengetahuan tentang formalin didapatkan hasil bahwa 9 penjual memiliki pengetahuan tinggi dan 6 orang memiliki pengetahuan rendah tentang formalin. Hasil analisis chi square didapatkan bahwa tidak ada hubungan antara penggunaan formalin pada ikan asin dengan pengetahuan penjual tentang formalin dengan nilai signifikasi 0,634 $(\mathrm{P}>0,05)$ dan nilai fisher exact test sebesar $1(>0,05)$ dan hasil uji kolerasi pearson menunjukan nilai signifikasi $0,662(\mathrm{p}>0,05)$.
\end{abstract}

Kata Kunci: formalin, pengetahuan formalin, ikan asin 
J.Gipas, November 2021, Volume 5 Nomor 2

ISSN 2599-0152 eISSN 2599-2465

http://jos.unsoed.ac.id/index.php/jgps

\section{PENDAHULUAN}

Ikan merupakan bahan pangan yang sering dijadikan sumber protein hewani oleh manusia. Ikan laut adalah sumber protein hewani yang penting untuk perkembangan mental pertumbuhan fisik dan anak (Farida, 2018). Ikan adalah bahan pangan yang memiliki sumber zat gizi esensial lengkap, berprotein tinggi, rendah kandungan lemak jenuh yang lebih menyehatkan dibandingkan dengan protein hewani lain (Artiningsih, 2021). Tingginya kandungan gizi ikan, menjadikan ikan segar mudah membusuk, terlebih lagi jika telah mati. Hal ini disebabkan oleh aktivitas mikroba pada jasad renik dari ikan tersebut. Ikan cepat membusuk dikarenakan kandungan air dari ikan sangat tinggi yaitu sebesar 60-84\% dari total beratnya (Antoni, 2011). Mudahnya ikan rusak ini, mempersulit nelayan dan pembudidaya dalam penyimpanan dan pendistribusian hasil panen. Salah satu cara pengolahan yang dapat memperpanjang umur simpan ikan, salah satunya dengan penggaraman untuk menghasilkan ikan asin.

Penggaraman ikan membuat ikan asin memiliki umur simpan lebih lama dikarenakan sifat garam yaitu bakteriostatik dan bakteriosidal, yang memiliki kemampuan untuk menunda pertumbuhan dan membunuh bakteri (Assadad dan Utomo 2011). Pengawetan ikan asin ini selain menggunakan garam sebagai zat pengawet, juga dapat menambahkan bahan tambahan pangan yang dapat membuat umur simpan lebih lama lagi. Akan tetapi pada kenyataannya, banyak produsen yang menggunakan zat pengawet berbahaya seperti formalin untuk mengawetkan ikan asin. Penggunaan formalin ini selain harganya murah, menurut Asep dalam wawancara Radar Sukabumi (2018) formalin juga dapat mengawetkan ikan asin dengan waktu yang cepat saat musim hujan. Ikan asin yang tidak menggunakan formalin memerlukan waktu paling sebentar tiga hari penjemuran, sedangkan ikan asin yang menggunakan formalin hanya membutuhkan waktu setengah hari untuk menjadi ikan asin (Anonim, 2018).

Formalin yang dicampurkan pada bahan pangan akan menjadi racun pada orang yang mengkonsumsinya, karena pada dasarnya formalin merupakan pengawet yang tidak boleh digunakan dalam makanan. Beberapa penelitian dan pengujian dilakukan terhadap ikan asin di berbagai daerah yang terbukti positif ber-formalin, seperti penelitian yang dilakukan oleh Ane et al., (2016) menunjukkan bahwa seluruh ikan asin sebanyak 31 sampel, positif 
J.Gipas, November 2021, Volume 5 Nomor 2

ISSN 2599-0152 eISSN 2599-2465

http://jos.unsoed.ac.id/index.php/jgps

mengandung formalin dengan kadar minimal $10 \mathrm{mg}$.

Penggunaan formalin pada makanan di Indonesia telah dilarang sejak lama. Larangan ini didasarkan pada Peraturan Menteri Kesehatan (Permenkes) permenkes 33 no 2012 dan Perka BPOM No.11 tahun 2019, dan PERKA BPOM No 9 Tahun 2020. Formalin dilarang penggunaannya dalam bahan makanan disebabkan karena sangat berbahaya jika dihirup dan mengenai kulit, apalagi tertelan. Jika dikonsumsi dalam jangka panjang, maka formalin dapat merusak hati, ginjal, limpa, pankreas, dan organ lainnya (Sari, 2017). Meskipun demikian, masih ada sebagian penjual atau produsen yang masih menggunakannya. Banyaknya kasus penggunaan formalin pada makanan terutama ikan asin, membuktikan bahwa penjual ataupun produsen pengetahuannya kurang. Pengetahuan merupakan modal utama dalam menentukan perilaku penjual dalam penggunaan formalin pada bahan pangan yang dijualnya (Habsah, 2012).

Hubungan pengetahuan penjual ikan asin dengan kandungan formalin di dalamnya, telah diteliti Rohmatillah (2015) dan Hidayatullah (2015). Penelitian serupa juga dilakukan oleh Widayanti et al. (2017), menyatakan bahwa terdapat hubungan yang signifikan antara tingkat pengetahuan penjual terhadap hasil identifikasi formalin.

Menurut Cahyadi (2012) beberapa ikan asin yang dijual di pasar tradisional Sukabumi pada tahun 2004 positif mengandung formalin. Sukabumi merupakan salah satu daerah yang terkena imbas dari pandemic Covid-19 termasuk pasar tradisional Sukabumi, sehingga mengakibatkan para penjual mengalami penurunan omset penjualan, termasuk penjual ikan asin, sehingga banyak ikan asin yang tidak terjual. Hingga saat ini, terdapat 11 pasar tradisional di Sukabumi yang belum pernah dilakukan penelitian mengenai pengetahuan penjual tentang formalin serta hubungannya dengan kandungan formalin pada ikan asin yang dijualnya. Tujuan penelitian ini adalah untuk mengetahui kandungan formalin pada beberapa ikan asin yang dijual di pasar tradisional Sukabumi serta hubungannya dengan pengetahuan penjual.

\section{METODE}

Bahan yang dgunakan adalah sampel ikan asin dari pasar Cibadak dan Cisaat Kabupaten Sukabumi yang mengambil ikan dari Muara Angke dan Pulau Pasaran, yang diketahui berformalin (Herliana, 2020; Yuliana 2011). Alat uji yang digunakan 
adalah seperangkat alat uji formalin atau test kit formalin dengan jenis reagen cair merk ET Easy Test.

Penelitian ini dilaksanakan pada bulan April sampai Juni 2021 di dua pasar tradisional di Sukabumi. Pengujian dilakukan di Laboratorium Sartika Universitas Djuanda Bogor.

\section{Pembuatan Kuesioner}

Penelitian ini dibagi menjadi dua tahap yaitu wawancara dan uji formalin. Tahap pertama yaitu wawancara dengan 7 pedagang ikan asin di pasar Cisaat dan 8 pedagang di pasar Cibadak Kabupaten Sukabumi. Kuesioner dibuat berdasarkan penelitian Safitri (2015) yang terdapat 14 pertanyaan mengenai BTP dan formalin.

\section{Uji Validitas dan Reabilitas}

Uji validitas dilakukan dengan mengukur nilai kolerasi antara pertanyaan dengan nilai total, tanpa mengikut sertakan pertanyaannya. Metode analisis yang digunakan adalah korelasi chi square dengan bantuan aplikasi SPSS, dengan menggunakan nilai sig 10\% dan ketentuan Jika nilai $r$ hitung $>r$ tabel, maka dinyatakan valid Jika nilai $r$ hitung $<\mathrm{r}$ tabel, maka dinyatakan tidak valid.

Uji reliabilitas pada penelitian ini dilakukan dengan cara Cronbach's Alpha yaitu menganalisis reliabilitas alat ukur dengan satu kali pengukuran menggunakan aplikasi program SPSS, dengan nilai sig $10 \%$ dan ketentuan Jika nilai $\mathrm{r}$ Alpha $>\mathrm{r}$ tabel, maka dinyatakan reliable. Sebaliknya bila nilai $r$ Alpha $<r$ tabel, maka dinyatakan tidak reliable.

\section{Pengumpulan data kuesioner}

Kuesioner yang telah divalidasi, diberikan kepada responden yang sebelumnya telah bersedia menandatangani surat kesediaan.

\section{Uji kadar Formalin}

Tahap kedua yaitu pengujian kadar formalin dalam sampel ikan asin di pasar Cisaat sebanyak 7 pedagang dan di pasar Cibadak sebanyak 8 pedagang. Teknik samplingnya adalah purposive sampling. Tiap pedagang diambil 2 sampel ikan secara acak dengan memilih ikan yang memiliki ciri-ciri seperti mengandung formalin, seperti ikan dapat tahan hingga lebih dari satu bulan pada suhu kamar, tampak lebih bersih dan cerah, baunya netral, tekstur ikan keras dengan bagian luar kering dan bagian dalamnya basah, dan tidak dikerubungi lalat (Saparinto dan Hidayati, 2006).

Pengujian formalin menggunakan test kits. Sampel dicincang, dimasukan $10 \mathrm{~g}$ sampel kedalam beaker glass $50 \mathrm{~mL}$ dan direndam dengan aquades, setelah itu sampel diambil sebanyak $1 \mathrm{~mL}$ dan 
J.Gipas, November 2021, Volume 5 Nomor 2

ISSN 2599-0152 eISSN 2599-2465

http://jos.unsoed.ac.id/index.php/jgps

dimasukan kedalam tabung reaksi dan ditambahkan reagen I dikocok dan ditambahkan reagen II, lalu amati perubahan warnanya. Apabila terbentuk warna ungu seulas hingga ungu pekat, maka sampel tersebut positif mengandung formalin. (Yulianti et al., 2021).

\section{Analisis Data}

Analisis data menggunakan analisis univariat untuk mendeskripsikan frekuensi setiap variable penelitian dan untuk menganalisis hubungan variable bebas dan terikat, dilanjutkan uji chi square dan kolerasi pearson (Larasati et al., 2019). Untuk mempermudah, mempercepat proses perhitungan dan mengolah data dalam penelitian ini, maka menggunakan bantuan perangkat lunak komputer yaitu SPSS (Statistical Product and Service Solution) for Windows versi 25.0.

\section{HASIL DAN PEMBAHASAN}

\section{Karakteristik Responden}

Berdasarkan hasil kuesioner yang terkumpul, maka sebanyak 15 responden dapat dikarakterisasikan sesuai dengan umur, jenis kelamin, pendidikan, jumlah ikan asin yang dijual per hari, asal ikan asin, dan pengetahuan responden.

Tabel 1. Karakteristik responden berdasarkan umur, jenis kelamin, dan pendidikan

\begin{tabular}{cccc}
\hline \multirow{2}{*}{ Karakteristik } & \multirow{2}{*}{ Keterangan } & \multicolumn{2}{c}{ Total } \\
\cline { 3 - 4 } & & Frekuensi (n) & Persentase (\%) \\
\hline \multirow{3}{*}{ Umur } & $17-25$ tahun & 6 & 40 \\
& 26-45 tahun & 7 & 46,7 \\
& 46-65 tahun & 2 & 13,3 \\
\hline \multirow{2}{*}{ Jenis kelamin } & Laki-laki & 12 & 80 \\
& perempuan & 3 & 20 \\
\hline \multirow{3}{*}{ Pendidikan } & tidak sekolah & 1 & 6,7 \\
& SD & 3 & 20 \\
& SMP & 1 & 6,7 \\
& SMA/SMK & 8 & 53,3 \\
& D3 & 1 & 6,7 \\
& S1 & 1 & 6,7 \\
\hline
\end{tabular}

Berdasarkan Tabel 1 diatas, diketahui bahwa usia responden di pasar Cibadak dan pasar Cisaat memiliki rentan usia terbanyak yaitu usia dewasa (26-45 tahun) sebesar $46,7 \%$, kemudian usia remaja
(17-25 tahun) yaitu sebesar $40 \%$. dan usia tua (46-65 tahun) yaitu sebesar 13,3\%. Umur termuda responden adalah 22 tahun dan umur tertua responden adalah 60 tahun. Menurut Yeni (2015) umur seseorang 
J.Gipas, November 2021, Volume 5 Nomor 2

ISSN 2599-0152 eISSN 2599-2465

http://jos.unsoed.ac.id/index.php/jgps

berpengaruh terhadap pengetahuannya,

karena orang yang lebih dewasa memiliki tingkat kemampuan dan kematangan dalam berfikir dan menerima informasi lebih baik dibandingkan dengan umur yang lebih muda atau belum dewasa. Umur yang lebih dewasa atau semakin tua umur dengan tingkat pendidikannya yang sejalan, semakin baik tingkat pengetahuannya dibandingkan dengan penjual dengan usia remaja atau muda (Darmastuti, 2018).

Berdasarkan karakteristik jenis kelamin diketahui bahwa jumlah penjual berjenis kelamin laki laki lebih banyak dibandingkan dengan penjual berjenis kelamin perempuan yaitu sebesar $80 \%$ atau 12 orang, dengan penjual yang berjenis kelamin perempuan sebanyak $20 \%$ atau 3 orang (Tabel 2).

Dari 8 orang penjual ikan asin di pasar Cibadak, 6 diantaranya berjenis kelamin laki laki dan 2 orang berjenis kelamin perempuan, sedangkan dari 7 orang penjual ikan asin di pasar Cisaat, 6 diantara nya berjenis kelamin laki laki dan seorang perempuan. Responden yang merupakan penjual juga dapat dikarakterisasi berdasarkan latar belakang pendidikan. Berdasarkan pendidikan maka responden paling banyak adalah responden dengan pendidikan Sekolah Menengah Atas (SMA) sebanyak 8 orang $(53,3 \%)$, kemudian responden yang tamat Sekolah Dasar (SD) 3 orang $(20 \%)$, responden tidak sekolah, Sekolah Menengah Pertama (SMP), D3 dan S1 masing masing 1 orang $(6,7 \%)$.

Berdasarkan data tersebut, didapatkan bahwa responden memiliki tingkat pendidikan yang cukup baik yaitu sekolah menengah pertama (SMP) dan sekolah menengah atas (SMA), bahkan ada yang berpendidikan tinggi yaitu D3 dan sarjana. Namun ada juga responden yang memiliki tingkat pendidikan yang kurang atau rendah yaitu tidak sekolah dan hanya sekolah dasar, tetapi memiliki kemampuan komunikasi yang baik, dilihat dari cara berbicara dan menyampaikan pendapat saat dilakukan wawancara dan pengisian kuesioner. Hal ini sejalan dengan pendapat Yeni (2015) bahwa tingkat pendidikan seseorang mempengaruhi kemampuan berfikir. Semakin tinggi latar belakang pendidikan diharapkan memiliki kemampuan pengetahuan lebih tinggi dibandingkan dengan seseorang yang latar belakang pendidikannya rendah. Pendidikan merupakan salah satu proses untuk menambah wawasan dan pengetahuan seseorang untuk mendewasakan diri dan meningkatkan kemampuan. 
Tabel 2. Karakteristik responden berdasarkan jumlah penjualan asal ikan

\begin{tabular}{cccc}
\hline \multirow{2}{*}{ Karakteristik } & Keterangan & Total \\
\cline { 3 - 4 } & & Frekuensi (n) & Persentase (\%) \\
\hline \multirow{3}{*}{ Rerata } & $5-50 \mathrm{Kg}$ & 11 & 73,3 \\
penjualan/hari & $51-100 \mathrm{Kg}$ & 3 & 20 \\
& $101-150 \mathrm{Kg}$ & 1 & 6,7 \\
& Total & 15 & 100 \\
\hline \multirow{2}{*}{ Asal ikan asin } & produksi sendiri & 0 & 0 \\
& suplier & 15 & 100 \\
\hline
\end{tabular}

Responden yang per harinya dapat menjual 5-50 kg sebanyak 11 orang (73,3,\%), kemudian sekitar 51-100 kg 3 orang (20\%), dan sekitar 101-150 kg/hari sebanyak 1 orang $(6,7 \%)$. Berdasarkan data tersebut, penjualan ikan asin di pasar Cibadak dan pasar Cisaat termasuk rendah, karena menurut Suhendi (2017) pada biasanya rata-rata penjualan perhari mencapai $100 \mathrm{~kg}$. Penurunan omset harian ini menyebabkan penumpukan ikan asin di toko.

Berdasarkan wawancara langsung dengan semua responden, diketahui bahwa seluruh penjual mengambil ikan asin dari supplier yang berasal dari luar kota yaitu Jakarta, Lampung, dan Banten. Tidak ada satupun penjual yang memproduksi sendiri ikan asinnya. Ikan asin dari Jakarta, tepatnya dari daerah Muara Angke, tempat tersebut merupakan daerah penghasil ikan asin terbesar di Jakarta (Kinapti, 2021). Ikan dari Lampung berasal dari daerah Pulau Pasaran, dan dari Banten adalah daerah Kronjo atau Pulau Cangkir.

\section{Pengetahuan}

Pengetahuan responden tentang formalin berdasarkan jawaban responden dalam kuesioner. Sebelum kuesioner diberikan kepada responden, terlebih dahulu dilakukan uji validitas dan reabilitas. Uji validitas merupakan pengujian untuk mengetahui ketepatan alat penilaian terhadap konsep yang dinilai sehingga betul betul menilai apa yang harus dinilai (Sudjana, 1996), sedangkan uji reliabilitas merupakan uji yang bertujuan untuk mengetahui sejauh mana tes dapat dipercaya untuk menghasilkan skor yang konsisten dan saling berkaitan tidak berubah meskipun diteskan pada situasi berbeda (Sugiyono, 2005). Hasil uji tersebut menunjukkan bahwa 12 soal dari jumlah keseluruhan 14 soal kuesioner valid dan reliable, oleh karena itu untuk soal kuesioner yang dipakai cukup 12 soal. 
Klasifikasi tingkat pengetahuan responden dilakukan berdasarkan pembandingan nilai median. Cara perhitungan median adalah dengan menjumlah nilai total skor yang dihasilkan lalu dibagi dengan jumlah responden. Hal ini sesuai dengan penelitian yang dilakukan oleh Safitri (2015) yang menyatakan bahwa untuk variable pengetahuan dikatakan "tinggi" jika jawaban benar melebihi median, sedangkan pengetahuan dikatakan "rendah" jika jawaban benar responden tidak lebih besar dari nilai median. Berdasarkan hasil perhitungan, nilai median pengetahuan didapatkan yaitu sebesar 29,3. Dengan begitu skor responden diatas 29,3 maka digolongkan pengetahuan tinggi dan apabila dibawah 29,3 dikatakan rendah.

Tabel 3. Tingkat pengetahuan penjual tentang formalin

\begin{tabular}{rcc}
\hline Tingkat & \multicolumn{3}{c}{ Total } \\
\cline { 2 - 3 } pengetahuan & Frekuensi (N) & Persentasi (\%) \\
\hline Tinggi & 9 & 60 \\
Rendah & 6 & 40 \\
\hline
\end{tabular}

Berdasarkan seluruh jumlah responden, tingkat pengetahuan dengan jumlah paling banyak adalah responden dengan pengetahuan yang lebih tinggi yaitu 9 orang (60\%), dan responden yang memiliki pengetahuan rendah sebanyak 6 orang (40\%). Responden yang memiliki pengetahuan tinggi paling banyak adalah responden dari pasar Cisaat yaitu sebanyak 5 orang dari 7 responden, sedangkan dari pasar Cibadak reponden yang memiliki pengetahuan tinggi sebanyak 4 orang dari 8 orang responden.

Dalam hasil kuesioner, pertanyaan tentang bahan tambahan pangan (BTP) sebagian besar penjual sudah mengetahui tentang bahan tambahan pangan. Hal ini menunjukan bahwa penyuluhan dan informasi tentang BTP yang disampaikan oleh TV, media social, serta penyuluhan dari pemerintah telah tersampaikan dengan baik kepada para penjual. Kemudian Hasil kuesioner tentang formalin menunjukan bahwa sebagian besar responden menjawab dengan baik. Kuesioner tentang peraturan pemerintah tentang formalin diketahui bahwa jawaban responden kurang baik. Hal ini disebabkan karena responden tidak dapat menghapal undang undang nomor berapa saja yang mengatur tentang penggunaan 
formalin, dan hanya mengetahui bahwa formalin dilarang digunakan dalam bahan pangan meski penyuluhan oleh pemerintah telah dilakukan serta informasi dari TV dan social media telah banyak dikeluarkan.

Hasil wawancara kuesioner yang dilakukan terhadap responden menunjukan bahwa keseluruhan responden lebih banyak memiliki pengetahuan yang tinggi. Hal ini disebabkan para penjual sendiri telah banyak mendengar tentang berita mengenai pengertian formalin serta bahaya formalin itu sendiri dari banyaknya berita yang disiarkan di TV, penyuluhan dari pemerintah yaitu BPOM dan Dinas Ketahanan Pangan serta teknologi yang telah maju sehingga berita tentang formalin mudah diterima oleh penjual. Hal ini sejalan dengan teori menurut Monk (1994) yang menyatakan bahwa salah satu yang mempengaruhi pengetahuan seseorang adalah informasi yang didapatkan, semakin banyak dan lengkap informasi yang didapatkan oleh seseorang maka semakin bertambah pula pengetahuannya.

Pengetahuan penjual di pasar Cibadak dan pasar Cisaat dilihat berdasarkan hasil wawancara serta karakteristik responden dengan tingkat pengetahuan penjual tidak ada keterkaitan satu sama lain, seperti tingkat pengetahuan yang berpendidikan cukup tinggi yaitu D3 termasuk rendah sedangkan pengetahuan responden yang berpendidikan rendah bahkan tidak sekolah memiliki tingkat pengetahuan yang tinggi. Begitupun berdasarkan umur dan jenis kelamin, jawaban dari responden tidak menunjukan bahwa umur lebih tua atau lebih muda memiliki pengetahuan yang tinggi maupun rendah atau penjual laki laki memiliki pengetahuan yang lebih tinggi maupun rendah dari perempuan. Menurut Febriyanto (2016) faktor yang dapat mempengaruhi tingkat pengetahuan selain dari pendidikan, jenis kelamin, serta umur adalah Informasi, budaya, dan pengalaman. Dengan begitu, hal yang menyebabkan tidak ada keterkaitan antara tingkat pendidikan, jenis kelamin dan umur dengan tingkat pengetahuan penjual dapat disebabkan oleh informasi yang didapatkan masing-masih berbeda. Selain itu, budaya dan pengalaman responden mengenai pengetahuan tentang formalin juga berbeda setiap orangnya.

\section{Hasil Uji Formalin}

Pengujian formalin dilakukan pada sampel yang telah diambil dari pasar Cibadak dan Cisaat dengan menggunakan kit uji formalin di UPT Sartika. Parameter dari pengujian ini adalah dengan terbentuknya warna ungu seulas hingga 
J.Gipas, November 2021, Volume 5 Nomor 2

ISSN 2599-0152 eISSN 2599-2465

http://jos.unsoed.ac.id/index.php/jgps

ungu pekat pada cairan sampel ketika ditambahkan reagen dari kit uji.

Tabel 4. Kandungan formalin pada sampel ikan asin

\begin{tabular}{cccc}
\hline Asal & Kandungan & \multicolumn{2}{c}{ Total } \\
\cline { 3 - 4 } Pasar & formalin & Frekuensi (n) & Persentasi (\%) \\
\hline Cisaat & Positif & 3 & 10 \\
& Negatif & 12 & 40 \\
\hline Cibadak & Positif & 1 & 3,3 \\
& Negatif & 14 & 46,7 \\
\hline
\end{tabular}

Berdasarkan hasil uji laboratorium terhadap kandungan formalin pada ikan asin didapatkan hasil $4(13,3 \%)$ dari 30 jenis ikan asin dari 15 penjual di pasar Cisaat dan pasar Cibadak positif mengandung formalin. Ikan asin yang positif mengandung formalin yang didapakan 3 dari pasar Cisaat dan 1 dari pasar Cibadak. Hal itu ditunjukan dengan adanya perubahan warna pada larutan sampel yang telah ditambahkan reagen $A$ dan reagen $B$ menjadi warna ungu bahkan seulas. Sedangkan 26 sampel lainnya tidak menunjukan perubahan yang serupa yang berarti sampel tersebut tidak mengandung formalin. Seperti penelitian yang dilakukan oleh Aristiyo et al (2016) bahwa sampel yang positif mengandung formalin akan berubah warna menjadi ungu seulas hingga pekat ketika ditambahkan reagen A dan reagen B pada saat pengujian. Terbentuknya warna ungu seulas hingga ungu pekat diakibatkan oleh adanya reaksi antara formaldehid dan 4-amino-3hidrazino-5-mercapto-1,2.4-Triazole

(BPOM, 2015).

Mekanisme formalin dalam mengawetkan produk adalah dengan cara mengaktivasi asam amino dalam protein sehingga membentuk rangkaian yang rapat dan berdekatan. Reaksi tersebut mengakibatkan protein mengeras dan tidak dapat larut (Herdianti, 2003). Dalam tubuh terdapat sel yang terbuat dari asam amino atau protein, sehingga ketika mengkonsumsi makanan berformalin akan menyebabkan kerusakan sel tersebut. Bahaya dari formalin itu sendiri diantaranya adalah apabila terhirup melalui system pernafasan maka akan segera diserap ke paru dan menyebabkan paparan yang akut berupa pusing, rhinitis, rasa terbakar, keluar air mata yang berlebihan sehingga menyebabkan kebutaan, bronchitis, edema pulmonary atau pneumonia karena dapat 
J.Gipas, November 2021, Volume 5 Nomor 2

ISSN 2599-0152 eISSN 2599-2465

http://jos.unsoed.ac.id/index.php/jgps

mengecilkan paru-paru dan menyebabkan terkumpulnya cairan di paru. Jika formalin masuk ke tubuh melalui sistem pencernaan sebanyak $30 \mathrm{~mL}$ maka akan menyebabkan kematian karena disebabkan oleh sifat korosif larutan formaldehida terhadap mukosa saluran cerna lambung, disertai mual, muntah, nyeri, pendarahan dan perforasi. Jika terpapar formalin secara terus menerus maka akan menyebabkan

\section{Hasil Uji Kolerasi Chi Square dan} Kolerasi Pearson Hubungan Pengetahuan Penjual dengan Penggunaan Formalin Pada Ikan Asin.

Hasil uji kolerasi diambil berdasarkan variable dimana variabel bebas nya adalah kerusakan pada ginjal, hati dan juga jantung (Widyaningsih, 2006).

Dalam agama Islam formalin dihukumkan haram karena tidak tayyib dan dapat membahayakan kesehatan. Sesuai dengan fatwa MUI Nomor 43 Tahun 2012 Tentang penyalahgunaan formalin dan bahan berbahaya lainnya dalam penanganan dan pengolahan ikan.

tingkat pengetahuan penjual terhadap bahan tambahan pangan formalin, dan variabel terikatnya adalah kandungan formalin pada sampel ikan asin.

Tabel 5. Hubungan kandungan formalin dengan tingkat pengetahuan penjual

\begin{tabular}{cccc}
\hline \multirow{2}{*}{ Tingkat Pengetahuan } & \multicolumn{3}{c}{ Kandungan Formalin } \\
\cline { 2 - 4 } & Negatif & Positif & Total \\
\hline Tinggi & 7 & 2 & 9 \\
Rendah & 4 & 2 & 6 \\
\hline Total & 11 & 4 & 15 \\
\hline
\end{tabular}

Berdasarkan hasil uji kolerasi chi square antara tingkat pengetahuan penjual dengan kandungan formalin didapatkan nilai signifikasi 0,634 ( $\mathrm{P}>0,05)$. Hasil pengujian ini masih terdapat 3 cell yang memiliki nilai expected count kurang dari 5, karena menurut Negara (2018) syarat penggunaan metode uji chi square adalah tidak boleh ada 1 sel saja yang memiliki frekuensi harapan atau disebut juga expected count ("Fh") kurang dari 5 sehingga penentuan hipotesis dilakukan dengan membaca uji fisher exact untuk menentukan hipotesis. Nilai exact sig (2-sided) fisher exact test sebesar $1(>0,05)$ 
maka dapat disimpulkan bahwa tidak ada hubungan yang signifikan antara tingkat pengetahuan penjual dengan kandungan formalin pada ikan asin di pasar Cibadak dan pasar Cisaat Kabupaten Sukabumi.

Selain itu, pada penelitian ini juga dilakukan analisisi kolerasi antara pengetahuan penjual tentang formalin dengan kandungan formalin pada ikan asin menggunakan uji kolerasi pearson. Uji ini dilakukan untuk mengetahui keeratan hubungan antar variabel. Berdasarkan hasil uji kolerasi pearson antara tingkat pengetahuan penjual dengan kandungan formalin didapatkan nilai $\mathrm{r}$ hitung adalah 0,123 yaitu lebih kecil dari $r$ tabel 0,514 yang menandakan bahwa kekuatan korelasi tingkat pengetahuan dengan perilaku pedagang dalam pengggunaan formalin pada ikan asin termasuk dalam kategori kekuatan korelasi sangat lemah. Menurut Sarwono (2009) nilai r 0 maka dikategorikan tidak ada kolerasi, 0,0-0,25 dikategorikan kolerasi sangat lemah, 0,025-0,50 dikategorikan kolerasi cukup, 0,05-0,75 dikategorikan kuat, 0,75-0,99 dikategorikan sangat kuat dan 1 dikategorikan sempurna. Selain itu, didapatkan nilai signifikasi $0,662(\mathrm{p}>0,05)$ yang artinya tidak terdapat hubungan yang bermakna antara dua variabel yang di uji.
Hasil pengujian menunjukan bahwa tidak ada hubungan antara pengetahuan penjual dengan penggunaan formalin. Hal ini ditunjukan dengan masih adanya penjual yang memiliki tingkat pengetahuan yang tinggi tapi sampel ikan asinnya menunjukan positif menggunakan formalin. Dilihat dari hasil penelitian terdapat dua responden yang memiliki pengetahuan tinggi dan dua orang responden dengan pengetahuan yang rendah masih menggunakan formalin dalam ikan asinnya (Tabel 5). Hal ini disebabkan karena penjual mengambil ikan asin dari supplier sehingga tidak mengetahui tentang bahan yang ditambahkan ke dalam ikan asin yang dijualnya. Hal ini juga diperkuat dengan hasil pengujian kolerasi antara tingkat pendidikan dengan kandungan formalin yang menunjukan bahwa tidak terdapat hubungan yang nyata dengan nilai signifikasi 0,358 . Pendidikan yang tinggi tidak dapat menjamin responden tidak menggunakan formalin, karena pada penelitian ini menunjukan bahwa penjual dengan tingkat pendidikan yang paling tinggi yaitu sarjana (S1) hasil pengujian terhadap sampel positif mengandung formalin. Penelitian ini sejalan dengan hasil penelitian Habibah (2013) yaitu tidak ada hubungan antara penggunaan formalin pada ikan asin dengan tingkat pengetahuan 
penjual ikan asin di pasar tradisional Kota Semarang. Penelitian ini juga sejalan dengan hasil penelitian Purnamasari (2020) yang mengungkapkan bahwa tidak ada hubungan yang signifikan antara pengetahuan penjual dengan penggunaan formalin dan boraks pada jajanan anak wilayah Kota Tanah Grogot tahun 2020. Responden memiliki pengetahuan yang cukup mengenai boraks dan formalin, tetapi masih terdapat jajanan yang mengandung boraks dan formalin.

Hasil penelitian ini tidak sejalan dengan Rohmatillah (2015), yang melaporkan adanya hubungan antara penjual dengan penggunaan formalin pada ikan asin yang dijual di pasar Tradisional diseluruh kota Mataram. Terlihat dari pengetahuan responden yang rendah tetapi tidak menggunakan formalin dalam ikan asin yang dijualnya. Perbedaan ini terlihat dari responnya saat dilakukan wawancara, bersikap terbuka terhadap peneliti, sedangkan responden dalam penelitian ini ada yang bersikap terbuka dan juga ada yang bersikap tertutup sehingga kemungkinan ada beberapa hal yang tidak sesuai fakta.

Faktor yang menyebabkan responden yang memiliki tingkat pengetahuan yang tinggi masih menggunakan formalin dalam penelitian ini adalah pengetahuannya yang masih hanya sebatas teori, sehingga tidak diaplikasikan dalam kehidupannya. Faktor selanjutnya yang mempengaruhi penjual masih menggunakan formalin adalah faktor ekonomi yang didasari oleh ketidakinginan penjual mengalami kerugian. Menurut responden saat dilakukan wawancara mengungkapkan bahwa kemungkinan ada beberapa ikan asin yang dijual mengandung formalin dikarenakan menginginkan keuntungan yang lebih dengan kondisi ikan asin yang lebih awet serta tampilan lebih menarik. Hal ini sejalan dengan penelitian Aristiyo (2016) yang menyatakan bahwa faktor dari penjual yang masih menggunakan formalin adalah ekonomi. Selain itu, dilihat berdasarkan jawaban hasil kuesioner dalam karakteristik responden berdasarkan asal ikan asin yang dijual, dapat menjadi faktor ketidak tahuan penjual mengenai ada tidak nya formalin dalam ikan asin yang dijualnya, karena seluruh responden menjual ikan asin yang berasal dari supplier. 
J.Gipas, November 2021, Volume 5 Nomor 2

ISSN 2599-0152 eISSN 2599-2465

http://jos.unsoed.ac.id/index.php/jgps

\section{KESIMPULAN DAN SARAN}

\section{Kesimpulan}

Hasil analisis formalin pada sampel ikan asin di pasar Cibadan dan pasar Cisaat Kabupaten Sukabumi didapatkan bahwa 4 dari 30 sampel ikan asin positif mengandung formalin. Hasil analisis pegetahuan penjual didapatkan bahwa penjual dengan pengetahuan yang tinggi yaitu 9 orang (60\%), dan penjual yang memiliki pengetahuan rendah sebanyak 6 orang (40\%). Hasil analisis chi square didapatkan bahwa tidak ada hubungan antara penggunaan formalin pada ikan asin dengan pengetahuan penjual tentang formalin dengan nilai signifikasi 0,634 (P>0,05) dan nilai fisher exact test sebesar $1(>0,05)$. Dan hasil uji kolerasi pearson menunjukan nilai signifikasi 0,662 (p>0,05) yang menunjukan bahwa tidak ada hubungan yang signifikan antar variabel dan nilai $\mathrm{r}$ hitung $0,123<\mathrm{r}$ tabel yang menunjukan bahwa kolerasi antar variabel termasuk lemah.

\section{Saran}

Penelitian selanjutnya diperlukan sampel ikan asin yang lebih banyak serta area pasar yang lebih luas lagi, seperti pasar satu kabupaten atau kota Sukabumi. Selain itu, variabel dapat ditambahkan seperti sikap penjual ikan asin terhadap kandungan formalin. Masyarakat perlu memiliki sifat lebih selektif terhadap bahan makanan yang akan dikonsumsi, serta perlu meningkatkan pengetahuan agar dapatdapat menghindari produk makanan terutama ikan asin yang mengandung formalin. Pemerintah perlu melakukan penyuluhan secara berkala dan rutin agar penjual dan produsen memiliki pengetahuan yang cukup mengenai bahan yang dilarang digunakan dalam produk makanan.

\section{DAFTAR PUSTAKA}

[BPOM] Badan Pengawasan Obat dan Makanan. 2018. Peraturan Kepala No. 7 Tahun 2018 Tentang Bahan Baku Yang Dilarang Dalam Pangan Olahan. BPOM. Jakarta

[BPOM] Badan Pengawasan Obat dan Makanan. 2020. Peraturan Kepala No. 13 Tahun 2020 Tentang Bahan Tambahan Pangan. BPOM. Jakarta

[DEPKES] Kementerian Kesehatan Republik Indonesia. 1999. Peraturan Menteri Kesehatan Republik Indonesia No. 772/Menkes/Per/IX/88 No. 1168/Menkes/Per/X/1999 Tentang Bahan Tambahan Pangan. Kemkes. Jakarta.

[MUI] Majelis Ulama Indonesia. 2012. Fatwa MUI No. 43 Tahun 2012 Tentang Penyalahgunaan Formalin Dan Bahan Berbahaya Lainnya Dalam Penanganan Dan Pengolahan Ikan. Jakarta

Ane, R., L. Selomo, M. dan Teda, I., Y. 2016. Kandungan formalin pada ikan asin yang dijual di pasar tradisional kota Makassar studi 
J.Gipas, November 2021, Volume 5 Nomor 2

ISSN 2599-0152 eISSN 2599-2465

http://jos.unsoed.ac.id/index.php/jgps

kasus: Pasar Terong, Pa'baengbaeng dan Toddopuli. Higiene 2(2): 108-113

Anonim. 2018. Awas Ikan Asin Berformalin. Radar Sukabumi [Internet]. Tersedia pada: https://radarsukabumi.com/kabupa ten-sukabumi/awas-ikan-asinberfomalin/. (4 Agustus 2021)

Anonim. 2020. Ikan asin berformalin. Jelang Siang TTV [Internet]. Tersedia pada:

https://www.youtube.com/watch? v=tJD7ymOtkMQ. (4 Agustus 2021)

Anonim. 2020. Penjualan ikan asin di Sukabumi menurun. Radar Sukabumi [Internet]. Tersedia pada:

https://pelitasukabumi.com/2020/ 11/22/11780/kota-sukabumi/ditengah-pandemi-omset-penjualanikan-asin-menurun/. (2 Juli 2021)

Antoni, S. 2011. Analisa kandungan formalin pada ikan asin dengan metoda spektrofotometri di kecamatan Tampan Pekanbaru [Disertasi]. Fakultas Tarbiyah dan Keguruan, Universitas Islam Negeri Sultan Syarif Kasim Riau.

Aristiyo, R., Nurul. A dan Salbiah. 2016. Hubungan tingkat pengetahuan produsen dengan penggunaan formalin pada baso sapi yang dijual di pasar tradisional dan modern Kota Pontianak. Sanitarian 8(3): 364-365

Artiningsih, Ni Kadek., Nursini, Ni Wayan., dan Kusumaningsih, Purwaningtyas. 2021. Kualitas sosis daging ikan kembung (rastrelliger kanagurt 1.) Dengan penambahan puree bit (beta vulgari 1.). Jurnal Gizi dan Pangan Soedirman 5 (1) : 92-104

Assadad, L., dan Utomo, B. S. B. 2011. Pemanfaatan garam dalam industri pengolahan produk perikanan. Balai
Besar Riset Pengolahan Produk dan Bioteknologi Kelautan dan Perikanan 6(1): 26-37

Cahyadi, W. 2012. Analisis dan Aspek Kesehatan: Bahan Tambahan Pangan. PT Bumi Aksara. Jakarta.

Darmastuti, A. 2018. Pengetahuan tentang keamanan pangan dan perilaku pada penjual makanan bergerak di wilayah Manahan. [Skripsi]. Fakultas Ilmu Kesehatan. Universitas Muhammadiyah Surakarta.

Farida, dan Roosita, Katrin. 2018. Kebiasaan konsumsi ikan laut, tingkat konsumsi, status gizi, dan prestasi belajar siswa sekolah dasar di daerah pantai dan bukan pantai. Jurnal Gizi dan Pangan Soedirman 2(2) : 1-15

Febriyanto, M., A., B. 2016. Hubungan antara pengetahuan dan sikap dengan perilaku konsumsi jajanan sehat di MI Sulaimaniyah Mojoagung Jombang. [Skripsi]. Fakultas Kesehatan Masyarakat. Universitas Airlangga Surabaya.

Habibah, T. P. Z. 2013. Identifikasi penggunaan formalin pada ikan asin dan faktor perilaku penjual di pasar tradisional Kota Semarang. Unnes Journal of Public Health 2(3): 1-10.

Habsah, 2012. Gambaran pengetahuan penjual mi basah terhadap perilaku penambahan boraks dan formalin pada mi basah di kantinkantin universitas $\mathrm{x}$ depok tahun 2012. [Skripsi]. Fakultas Kesehatan Masyarakat. Universitas Indonesia

Herdianti. 2003. Analisis bahan tambahan kimia (bahan pengawet dan pewarna) yang dilarang digunakan dalam makanan jajanan.[Skripsi] Fakultas Teknik Universitas Pasundan. Bandung.

Herlina, A. 2020. Analisis formalin pada ikan asin dipusat pembuatan ikan 
J.Gipas, November 2021, Volume 5 Nomor 2

ISSN 2599-0152 eISSN 2599-2465

http://jos.unsoed.ac.id/index.php/jgps

asin Pulau Pasaran Kelurahan

Kota Karang Kecamatan Teluk

Betung Timur tahun 2020.

[Skripsi]. Jurusan Kesehatan

Lingkungan. Kementerian

Kesehatan Republik Indonesia.

Politeknik Kesehatan Tanjung

Karang

Kinapti, T., T. 2021. Mengintip proses pengolahan ikan asin di Muara Angke. Merdeka.com 26 Maret 2021. [Internet]. Tersedia pada: https://www.merdeka.com/travel/ mengintip-proses-pengolahanikan-asin-di-kampung-nelayanmuara-angke.html. Juni 2021.

Larasati, E., Astuti, D., dan KM, S. 2019. Hubungan pengetahuan penjual dengan penambahan boraks dan formalin pada jajanan olahan daging di sekitar Universitas Muhammadiyah Surakarta. [Skripsi]. Program Studi Kesehatan Masyarakat. Universitas Muhammadiyah. Surakarta.

Monks F.J.K dan Haditono. 1994. Psikologi Perkembangan. Cetakan ke IX. Gadjah Mada University Press. Yogyakarta.

Negara, I., C. 2018. Penggunaan uji chisquare untuk mengetahui pengaruh tingkat pendidikan dan umur terhadap pengetahuan penasun mengenai hiv-aids di Provinsi Dki Jakarta. Di dalam Prosiding Seminar Nasional Matematika dan Terapannya 2018 p-ISSN: 2550-0384; e-ISSN: 2550-0392

Purnamasari, N.A., Hayati, R., \& Chandra. 2020. Hubungan pengetahuan dan sikap penjual makanan jajanan terhadap penggunaan formalin dan boraks di wilayah Kota Tanah
Grogot Tahun 2020. Journal of Public Health: 28-34.

Rohmatillah, S.N.A. 2015. Korelasi antara nilai pengetahuan dengan perilaku penjual dalam penggunaan formalin pada ikan asin di pasar tradisional Se-Kota Mataram. [Skripsi]. Fakultas Kedokteran. Universitas Mataram.

Safitri, A.R. 2015. Gambaran pengetahuan, sikap, dan perilaku penjual tahu mengenai tahu berformalin di pasar daerah Semanan Jakarta Barat tahun 2015. [Skripsi]. Program Studi Kesehatan Masyarakat. Fakultas Kedokteran dan Ilmu Kesehatan. Universitas Islam Negeri Syarif Hidayatullah. Jakarta

Saparinto, C. Hidayati, D. 2006. Bahan Tambahan Pangan. Kanisius. Yogyakarta

Sari, Y. I. P. (2019). Identifikasi formalin pada ikan laut yang dijual di pasar antri cimahi. Jurnal TEDC 11(2): 126-130.

Sarwono, J. 2009. Statistik Itu Mudah: Panduan Lengkap untuk Belajar Komputasi Statistik Menggunakan SPSS 16. Universitas Atma Jaya. Yogyakarta

Sudjana, 1996. Metode Statistika, Penerbit Tarsito. Bandung

Sugiyono. 2005. Memahami Penelitian Kualitatif. CV. Alfabeta. Bandung Suhendi. 2017. Penjualan ikan asin di pasar $X$ Kabupaten Sukabumi menurun 70 persen. Sukabumi Update. 8 Februari 2017

Widayanti, N. P. dan Ayu, L.S. 2017. Hubungan tingkat pengetahuan penjual terhadap identifikasi formalin pada ikan asin di Pasar Tradisional Kota Denpasar Tahun 
2017. Jurnal Ilmiah Medicamento 3(1): 44-47.

Widyaningsih, TD. 2006. Alternatif Pengganti Formalin Pada Produk Pangan. Trubus Agrisarana. Surabaya

Yeni, P.,S.,I. 2015. Faktor-faktor yang berhubungan dengan pengetahuan penggunaan obat generik pada masyarakat di wilayah kerja puskesmas Padang Panyang Kabupaten Nagan Raya tahun 2015. [Skripsi]. Program Studi Ilmu Kesehatan Masyarakat. Fakultas Kesehatan Masyarakat Universitas Teuku Umar. Padang Yuliana, E., Suhardi, D.,A., dan Susilo, A. 2011. Tingkat penggunaan bahan kimia berbahaya pada pengolahan ikan asin: kasus di Muara Angke Dan Cilincing, Jakarta. Jurnal Pengolahan Hasil Perikanan Indonesia 14(1): 14-21

Yulianti, Cicik H., dan Safira, Aldila Nur. 2020. Analisis kandungan formalin pada mie basah menggunakan nash dengan metode spektrofotometri UV-Vis. Journal of Pharmacy and Science 5(1): 7-14 